\title{
Do Black Lives Matter in Post-Brexit Britain?
}

\author{
Anthony G. Reddie
}

\begin{abstract}
This paper speaks to existential challenges facing Black people, predominantly of Caribbean descent, to live in what continues to be a White dominated and White entitled society. This paper, working against the backdrop of the 'Black Lives Matter' Movement that originated in the United States, analyses the socio-political and cultural frameworks that affirm Whiteness whilst concomitantly, denigrating Blackness. The author, a well known Black liberation theologian, who is a child of the Windrush Generation, argues that Western Mission Christianity has always exemplified a deep seated form of anti-Blackness that has helped to shape the agency of Black bodies, essentially marking them as 'less than'. This theological base has created the frameworks that have dictated the sematic belief that Black bodies do not really matter and if they do, then they are invariably second class ones when compared to White bodies. In the final part of the paper, the author, outlines the ways in which Black theology in Britain, drawing on postcolonial theological and biblical optics has sought to critique the ethnocentrism of White Christianity in Britain in order to assert that 'Black Lives Do Matter'.
\end{abstract}

Keywords: Windrush Generation, Mission Christianity, Black Lives Matter, Colonialism, Whiteness.

We have recently marked the $50^{\text {th }}$ anniversary of Enoch Powell's 'Rivers of Blood Speech'. Enoch Powell's infamous 'Rivers of Blood Speech'1 ${ }^{1}$ occurred at a time when concerns over immigration from 'New Commonwealth' contexts such as the Caribbean and the Indian subcontinent was causing alarm. Enoch Powell, White British Conservative politician, made his inflammatory speech on the $20^{\text {th }}$ April 1968 , expressing his disquiet at the levels of Black and Asian immigration from the New Commonwealth, believing that these growing communities would destabilize Britain and would disempower and marginalise indigenous White people. His speech was seen as a cause celebre in terms of the history of race-relations in the UK.

\footnotetext{
${ }^{1}$ For further details on this significant event in contemporary British history, see the following link: https://news.sky.com/story/enoch-powells-rivers-of-blood-the-speech-that-divided-a-nation-11339291 (Accessed 20th June 2018)
} 
Whilst Edward Heath, leader of the opposition Conservative Party, sacked Powell from the shadow cabinet, thousands of trade unionists at the time sent in letters of support for Powell, supporting his stance on Black and Asian immigration. On the thirtieth anniversary of the speech in $1998,64 \%$ of a Channel 4 studio audience brought together to discuss the legacy of his speech believed that Powell was not a racist but a courageous nationalist. In the early part of 2018 , there was a contentious proposal to mount a historic blue plaque in Wolverhampton in Enoch Powell's honour as a former distinguished MP for the city. The BBC in its wisdom chose to broadcast the speech in full, citing it of 'historic importance' in the nation's contemporary history, despite the complaints of many Black people, critiquing its incendiary, bombastic rhetoric as deeply problematic and inimical to any helpful sense of community relations in the UK.

What I want to argue in this paper is that whilst the surface level indices of social, cultural and economic opportunities for Black people have improved, what has remained largely unchanged is the unreconstructed, substantive underpinning notions of what it means to belong and be acceptable in Britain - that in effect, Black people are still the 'other' in this context. We are not authentically of this place in the fashion that is readily accepted by White subjects in this nation.

This paper is written against the backdrop of Brexit. Its concerns are not concerned with the specifics of whether Britain should remain in or leave the European Union. At the time of writing, Britain is mired in the political paralysis of whether to leave the EU and if so then on what terms, indeed if we choose to leave at all. This paper offers no opinion on the political matter of remaining or leaving. This ambivalence arises from the belief that whether we do so or not, nothing will change the toxic climate that has been unleashed by the Leave Campaign. Whether Britain leaves or not, a majority of the nation has spoken its mind, in terms of aligning with a toxic, xenophobic fuelled subtext of the Leave Campaign that othered visible 
minorities and created an explicit White centred discourse around the nature of Britishness and notions of belonging. The topicality of Brexit will wane but the sense that Britain has been dragged back into 'dark ages' Enoch Powell rhetoric around 'Rivers of Blood' will not be dissipated anytime soon.

I am part of a wider community. The mass migratory movement of Black people from Africa and the Caribbean in the years following the end of the World War II is termed the 'Windrush' epoch. This migratory movement commenced with the arrival of 492 Caribbean people at Tilbury docks on the ship The SS Empire Windrush, on the $22^{\text {nd }}$ June 1948.

\section{Anti-Blackness in Mission Christianity}

The critical construction of Black bodies as the other within the body politic of the nation finds its underscoring in the development of Mission Christianity, out of which emerged the critical dialectic of oppressed Black bodies and White hegemonic power. In using the term 'Mission Christianity' I am speaking of a historical phenomenon in which there is existed (and continues to this day) an interpenetrating relationship between European expansionism, notions of White superiority and the material artefacts of the apparatus of Empire. This form of Christianity became the conduit for the expansion of Eurocentric models of Christianity in which ethnocentric conceptualisation of civilisation gave rise to notions of superiority, manifest destiny and entitlement. ${ }^{2}$ The problem with the historical enactment of Western Missionary Christianity as it is arose from the mandates outlined in the "Great Commission,"3

\footnotetext{
${ }^{2}$ See T.J. Gorringe Furthering Humanity: A Theology of Culture (Basingstoke: Ashgate, 2004). See also John M. Hull Towards the Prophetic Church: A Study of Christian Mission (London: SCM press, 2014).

${ }^{3}$ The nomenclature often identified as "The Great Commission" is seen as the primary proof text for legitimizing the missionary intent of the Christian faith as it pertains to non-European cultures and contexts. For the purposes of this essay, the relevant words of the "Great Commission" are to be found in Matthew 28, vv. 20, which states "and teach them to do everything I have told you." The teaching ministry of the church has arisen from the mandate to "make new disciples" of Jesus Christ. The establishment of new churches in the Mediterranean during the second half of the first century of the "Common Era" was often predicated on the replication of Christian ideas, combined with human socialization in the power of the Holy Spirit, in which, new recruits were placed in proximity with more established believers within a powerful framework of an emerging Christian narrative. See Stanley Hauerwas, "The Gesture of a Truthful Story," in Jeff Astley, Leslie J. Francis, and Colin Crowder, eds., Theological Perspectives on Christian Formation: A Reader on
} 
was that, allied to Eurocentric notions of superiority and White supremacy, it assisted in giving rise to European mercantilist expansion, and the conquest of non-European cultures. African American Womanist theologian Linda Thomas critiques the Matthean tradition of mission, arguing that the locus of power lies with those who are sent as opposed to those who are the recipients of such missionary activities. ${ }^{4}$ The missionary impulse of the "Great Commission" was interpreted as a means of imposing Eurocentric values on the cultures of non-European peoples across the world, arising on the basis of the superiority of White European religio-cultural aesthetics and theological norms.

Western Missionary Christianity formed a collusive relationship with White European hegemony that assisted in providing the theological under-scoring for the transatlantic slave trade. When English travellers first began to encounter Black people on a prolonged basisparticularly, through their excursions onto the African continent-it soon became clear that their existing notions of anti-Blackness were buried deep in their theology, which helped to give rise to dangerous notions of African "otherness." ${ }^{5}$ The tensions and contradictions between religion, faith, ethnicity and nationality were exploited by means of "specious" forms of Biblical interpretation. One of the main "proof" texts that resolved the issue for justifying the enslavement of Africans within a Christian framework was Genesis 9:18-25 — "The Curse of Ham." Noah punishes his son Ham by cursing his own grandson Canaan (the son of Ham), condemning him and all his descencents to slavery. ${ }^{6}$

Whilst the solidified boundaries and binaries between Whiteness and Blackness were being played out in the Mission field across the broad contours of the British Empire, there was also

Theology and Christian Education (Grand Rapids, MI: Wm. B Eerdmans, 1996), pp.97-105. See also Craig Dykstra, "No Longer Strangers: The Church and its Educational Ministry," in Jeff Astley, Leslie J. Francis, and Colin Crowder, eds., Theological Perspectives on Christian Formation, pp.106-18.

${ }^{4}$ See Linda E. Thomas, "Anthropology, Mission and the African Woman: A Womanist Approach," Black

Theology: An International Journal 5, no.1 (2007): 11-19.

${ }^{5}$ See Ron Ramdin, Reimaging Britain (London: Pluto Press, 1999), 5-10.

${ }^{6}$ See Stephen R. Haynes, Noah's Curse: The Biblical Justification of Slavery (Oxford \& New York: Oxford University Press, 2002). See also Sylvester A. Johnson, The Myth of Ham in Nineteenth-Century American Christianity (New York: Palgrave Macmillan, 2004). 
a more subtle form of dichotomous discourse in evidence within the borders of the British nation state.

I would argue that the normativity of racialised forms of 'othering' within Britain has always existed within context of a religio-cultural and political framework. The 1662 Act of Uniformity, following the Restoration of King Charles II to the monarchy, states in its preamble the notion that uniformity is a pre-requisite to unity. ${ }^{7}$ The stark effect of this Anglican-centred conflation between crown, church and state was the marginalisation of nonconformism in Britain and the supremacy of the Church of England. In effect, Britain became a one-church-state oligarchy.

Seventeenth century Britain had already learnt how to persecute White people who were considered different long before Black people entered the nation in significant numbers. Nonconformist people were targeted as the aberrant other for their refusal to comply with the legislative religio-political orthodoxy of the 'Clarendon Code'. Those who were othered as dangerous to the body politic of the nation were also White like those who were persecuting them. Isiorho argues that the Church of England, with its links in the landed aristocracy and middle class privilege serves as a crude barometer for a symbolic notion of Whiteness and English normalcy within the psyche of the nation. ${ }^{8}$ The impetus for the aforementioned arises from the sublimated theologies of election that are codified in the supremacy of Whiteness in which there remains deep seated notions of exceptionalism and entitlement, bolstered by empire and colonialism.

R.S. Sugirtharajah, the doyen of Postcolonial Biblical hermeneutics, once noted that the relationship between British Christianity and empire is one that has been suffused with a collusive sense of mutuality. ${ }^{9}$ For both the Christian faith and imperialism, and the regimes

\footnotetext{
${ }^{7}$ See Church of England. - Facsimile of the original manuscript of the Book of Common Prayer (London: C. J. Clay \& Sons, 1891).

${ }^{8}$ David Isiorho 'Black theology in Urban Shadow', pp.29-48

${ }^{9}$ See R.S. Sugirtharajah Postcolonial Reconfigurations: An Alternative Way of Reading the Bible and Doing Theology (London: SCM press, 2003), pp.143-161
} 
that connote the latter do so on the basis of presuming themselves to be superior to the phenomenological entities they seek to usurp or supplant. Speaking with particular attention to the question of empire, Sugirtharajah writes

Empires are basically about technically and militarily advantaged superior 'races' ruling over inferior and backward peoples. When imperial powers invade, the conquered are not permitted to be equal to the invaders. This was true of all empires, Roman to British and American. The basic assumption of superiority is never questioned in their writings. ${ }^{10}$

The illusory superiority of Britain is built upon a bedrock of Christian inspired notions of exceptionalism in which God has set apart the British, particularly, the English, to occupy a special place in the economy of God's Kingdom. One can see an element of this in the rhetoric of Britain's greatest writer William Shakespeare, who in his play Richard II, written in $1595 / 6$, a few years after the Spanish Armanda of 1588, states in unambiguous tones, the import of the English when thinking in terms of their sense of exceptionalism. Shakespeare writes

This royal throne of kings, this sceptered isle, This earth of majesty, this seat of Mars, This other Eden, demi-paradise, This fortress built by Nature for herself Against infection and the hand of war, This happy breed of men, this little world, This precious stone set in the silver sea, Which serves it in the office of a wall Or as a moat defensive to a house, Against the envy of less happier lands,--This blessed plot, this earth, this realm, this England. ${ }^{11}$

The outworking of this exceptionalism was the desire to export the superiority of the British across the world. Empire and colonialism found much of its intellectual underscoring on the basis of White, Eurocentric supremacy, which marked the clear binary between notions of civilised and acceptable over and against uncivilised and transgressive. ${ }^{12}$ There are no prizes for guessing on which side of the divide Black people, for example, found themselves. Much

\footnotetext{
${ }^{10}$ R.S. Sugirtharajah Postcolonial Reconfigurations, p. 147

${ }^{11}$ See John of Gaunt's death-bed speech in Act 2, scene 1 where he prophesizes the downfall of an idealized England under the rule of Richard II. William Shakespeare Richard II. (Stratford: Arden Shakespeare Series, 2003).

${ }^{12}$ Anthony B. Pinn Terror and Triumph: The Nature of Black Religion (Minneapolis: Fortress press, 2003), pp.27-79
} 
of the epistemological weight for the buttressing of colonialism, when approached through the refracting lens of Christian faith, has been the seeming invisible trope of Whiteness.

\section{Demonization of the Black Body}

A central feature of Mission Christianity was its construction of the Black body as other. To understand why Black bodies do not matter in Postcolonial, Post Brexit, Britain, we have to remind ourselves that in Mission Christianity, the Black body and therefore the lives attached to those bodies were considered expendable. Anthony Pinn has undertaken detailed work investigating the dialectic of the existential, material realities of Black bodies and the phenomenon that is Christianity. ${ }^{13}$ In Terror and Triumph, Pinn rehearses the contested and troubled relationship between White slave holding Christianity and Black bodies, outlining the levels of demonization and virulent denigration that provided the essential backdrop to transatlantic chattel slavery. ${ }^{14}$ Outlining the apparent ease and the complicity with which Christianity colluded with the epistemological frameworks that underpinned the machinery of slavery, Pinn writes

In short, Scripture required that English Christians begin their thinking on Africans with an understanding that Africans had the same creator. Yet they were at least physically and culturally different, and this difference had to be accounted for. As we shall see, a sense of shared creation did not prohibit a ranking within the created order, one in which Africans were much lower than Europeans. ${ }^{15}$

The sense of a deep prevailing anti-Black sentiment replete with notions of Greek antiquity ${ }^{16}$ and practiced within Western (particularly English), Missionary Christianity was given

\footnotetext{
${ }^{13}$ See Anthony B. Pinn, Terror and Triumph: The Nature of Black Religion (Minneapolis, MN: Fortress Press, 2003). See also Anthony B. Pinn and Dwight N. Hopkins, eds., Loving The Body: Black Religious Studies and the Erotic (New York: Palgrave Macmillan, 2004) and Anthony B. Pin, ed., Black Religion and Aesthetics: Religious Thought and Life in Africa and The African Diaspora (New York: Palgrave Macmillan, 2009).

${ }^{14}$ Pinn, Terror and Triumph, p.1-80.

${ }^{15}$ Pinn, Terror and Triumph, p.6.

${ }^{16}$ This phenomenon and theme has been explored by Robert E. Hood, Begrimed and Black: Christian

Traditions on Blacks and Blackness (Minneapolis, MN: Fortress Press, 1994).
} 
added piquancy in the deliberate attempt to use the developments of early Christian theology as a means of reinforcing the essentially depraved and base status of the Black body. ${ }^{17}$

Kelly Brown Douglas demonstrates how a particular outworking of Pauline, platonized theology (one that downplays the concrete materiality of the body in favor of the abstract and the spirit) was used as a means of demonizing Black bodies. ${ }^{18}$ Kelly Brown

Douglas writes

Accordingly, it is platonized Christianity that gives rise to Christian participation in contemptible acts and attacks against human bodies, like those against Black bodies. Not only does platonized Christianity provide a foundation for easily disregarding certain bodies, but it also allows for the demonization of those persons who have been sexualised. ${ }^{19}$

One can amplify the prevailing sense of an incipient anti-Black strain within the corporate edifice of Western Missionary Christianity when one considers the ways in which Black Christianity itself has imbibed the strictures against the Black body in its own corporate operations of religiosity. Anthony Pinn, drawing on a similar analysis of Platonized, Pauline theology, argues that Black Christianity in the USA and the UK also, has imbibed the prevalent suspicion surrounding the Black body. It has taught many Black Christians to remain at best indifferent to the material needs of the Black body or to seek to transcend its supposed, despised nature; this demonization emerging from the tenets of White Christian slaveholding, thought and practice. ${ }^{20}$

The product of this continued sense of the ongoing demonization of Blackness can be seen in the ways in which Britain has remained ambiguous at best to the material and cultural

\footnotetext{
${ }^{17}$ This idea is taken from Kelly Brown Douglas' excellent study on Black bodies and how they have been policed and controlled within the religious framework of Christianity. See Kelly Brown Douglas, What's Faith Got To Do With it? Black Bodies/Christian Souls (Maryknoll, NY: Orbis, 2005).

${ }^{18}$ Kelly Brown Douglas What's Faith Got To Do With it?, pp.3-38.

${ }^{19}$ Kelly Brown Douglas What's Faith Got To Do With it?, p.37

${ }^{20}$ Anthony Pinn "Introduction," in Loving The Body, pp.1-8.
} 
realities of Blackness. The continued sense of contested notions of self as it pertains to engaging with issues of Blackness remains replete within British Christianity. It can be argued that this dialectical struggle has its roots in the misinformation imparted to Black people by their slave masters during the epoch of slavery and in the era of colonialism. ${ }^{21}$

Black British Pastoral theologian, Delroy Hall has written movingly and persuasively, on the Windrush generation in Britain, describing our existence as one of 'Existential Crucifixion'. ${ }^{22}$ Hall argues that Diasporan African peoples have endured the horrors of 'Good Friday' and our existential crucifixions at the hands of White hegemony, through the privations of slavery, colonialism and neo-colonialism, but the exulting freedom of 'Easter Sunday' has yet to materialize. In effect, Diasporan African peoples are still wrestling with an acute sense of being mired in 'Low Saturday' or 'Holy Saturday', stuck in a socio-religious and political form of liminality that speaks to the transformative nature of redemptive suffering that has thus far proved to be anything but redemptive. ${ }^{23}$ The continued marginalization and suffering of Black people has raised an important, if not seemingly insoluble theological problem of trying to correlate the agency of an omnipotent God with the ongoing negation of faithful peoples who have called repeatedly on God to end their existential travails, but to no avail! It is interesting to note the extent to which those on the political right are now using religion and the construction of Whiteness and Christianity as a means of arguing against the continued presence of Black and Asian people in Britain on the grounds that we are threatening the 'Christian heritage of the nation', i.e. Christianity equals Whiteness. ${ }^{24}$ So a form of subterranean Whiteness becomes emblematic for the socio-cultural and political framing of belonging that constructs semiotic borders within the body politic that is Britain.

\footnotetext{
${ }^{21}$ See the work of the great African American historian Carter G. Woodson for work that reflects on the notion of identity struggle of Black people that often arises from various forms of mis-education organized and perpetrated by White power. See Carter G. Wood- son, The Mis-Education of the Negro (Trenton, NJ: Africa World Press, [1933] 1990).

${ }^{22}$ See Delroy Hall 'The Middle Passage as Existential Crucifixion'. Black Theology: An International Journal, Vol.7, No.1, 2009, pp.45-63.

${ }^{23}$ Delroy Hall, 'The Middle Passage as Existential Crucifixion', pp.46-54

${ }^{24}$ See The Methodist Recorder - Front page story, $16^{\text {th }}$ March, 2006
} 
In effect, the furore caused by the attempted deportation of the Windrush Generation is predicated on a semantic demarcation between Whiteness and Blackness, in which the boundaries between the Whiteness of belonging and the otherness of Blackness of the Windrush Generation is such that even the normal rules of civility around nationality and common decency; are exposed as illusionary. African American Womanist Ethicist Emilie Townes has written about the cultural construction of evil via the media depictions of Blackness, and how the toxic ephemera of the media exacerbate this hegemonic dynamic of White supremacy. ${ }^{25}$ Townes' penetrating analysis of the cultural production of western life reminds us of the embedded ways in which Blackness is fixed in the popular imagination. ${ }^{26}$

The objectification of Blackness is echoed in the literary and media production that is resonant in the public landscape of the west, particularly, in the US. ${ }^{27}$ One can see this displayed quite markedly in a high profile interview between Piers Morgan and Diane Abbott on 'Good Morning Britain', following the furore over the deportation of the Windrush Generation. Morgan repeatedly asked Diane Abbott to clarify her position and that of the Labour party regarding levels of illegal immigration her party would tolerate in Britain, linking that to the Windrush Generation. The tendentious point Morgan seemed to want to make was linking the Windrush generation to the issue of illegal immigration. The Windrush Generation are NOT illegal immigrants, but British citizens, many of whom came to Britain on British passports. My own parents travelled to Britain from Jamaica in 1957 on British passports because at that point in history, Jamaica was still a crown colony and a part of British Empire and would not achieve her independence until August 1962. And yet, despite the repeated reminders that this issue was one of callous racism at the behest of the British

\footnotetext{
${ }^{25}$ See Emilie M. Townes Womanist Ethics and the Cultural Production of Evil (New York: Palgrave Macmillan, 2006)

${ }^{26}$ Emilie M. Townes Womanist Ethics, pp.11-55

${ }^{27}$ Emilie M. Townes Womanist Ethics, pp.29-55
} 
state and not one of illegal immigration, Morgan continued to press Abbott about illegal immigration. ${ }^{28}$ Morgan's insistence on linking the Windrush Generation to illegal immigration simply reminds us that even legal Black British subjects are somehow intrinsically illegal, no matter what the law may state, simply by virtue of our Black skin.

Blackness is othered behind a culturally constructed, media influenced wall, that situates the Windrush Generation as the seemingly disposable entities on the sharp end of the vituperative rhetoric of entitled Whiteness that provides the underpinning of Britishness.

\section{The Problematics of -Black People in Britain}

The recent furore in the UK around the potential deportation of Caribbean migrants has galvanized the body politic of the nation in ways that have proved surprising and challenging for many. The sense of outrage felt by many ordinary British people has surprised many in the news media. The construction of the binary of the privilege of Whiteness juxtaposed with those who are othered is one that is replete within the English psyche. The recent actions of the government in trying to deport Black Caribbean people whose citizenship was held in question due to governmental conspiracy or incompetency was but the sharp end of a continuum of the racialization of Black bodies that has been centuries in the making. ${ }^{29}$ The virulently racist treatment meted out to Black people of the Windrush Generation is all the more unpalatable in that it exacerbates the already pernicious nature of being 'othered' in a nation that often wants to exemplify homogeneity and sameness. The statistics that surround Black and Asian lives in Britain largely make for grim reading. Living here is never easy or

\footnotetext{
${ }^{28}$ For a precis of the interview see the following link: - http://www.itv.com/news/2018-04-30/diane-abbottclashes-with-tv-host-piers-morgan-over-immigration/ - Accessed $25^{\text {th }}$ July 2018

${ }^{29}$ See the following link for a brief introduction to the controversy surrounding the deportation of Black Caribbean migrants. http://www.theweek.co.uk/92944/who-are-the-windrush-generation-and-why-are-theyfacing-deportation
} 
without its struggles. The vast bulk of our numbers, for example, remain at the bottom of the socio-economic ladder. ${ }^{30}$

The irony of our residency in this country is that it has never been a benign or non-contested existence. The socio-politicised nature of Black bodies residing in Britain is neither a new nor a surprising phenomenon. ${ }^{31}$ Once you start from the premise that some people really do belong and deserve to do so and others do not, then it becomes almost axiomatic that particular practices will develop and legislation be passed which in turn; lead to the penalising and detrimental treatment meted out to Black people.

The racist frameworks of 'them' and 'us' create the template in which stereotyping, discrimination and marginalisation become commonplace, leading to the blunt instrument of loyal and largely supine Black people being threatened with deportation when they have been British citizens of many years standing. The punishment of Black people fits into a long established pattern, deep within White religious discourse, that Black people and other minority ethnic peoples deserve to be ill-treated, because deep down, they are not of the same substance as 'normal White people'. ${ }^{32}$ That is, notions of ontological difference between Whiteness and Blackness continue to underpin how we assess the qualitative importance of the latter in the body politic of the nation.

Thinking back to the death of the Black teenager, Stephen Lawrence, now more than twentyfive years ago, is a painful reminder of the disposability of Black bodies. Stephen Lawrence

\footnotetext{
${ }^{30}$ See Ceri Peach 'Black-Caribbeans: Class, gender and geography'. Ceri Peach (ed.) Ethnicity in the 1991 Census - Vol.2 The Ethnic Minority Populations of Great Britain (London: HMSO, 1996, pp.27. See also Kehinde Andrews Resisting Racism: Race, inequality, and the Black supplementary school movement (StokeOn-Trent: Trentham press, 2013)

${ }^{31}$ See Bob Carter, Clive Harris and Shirley Joshi 'The 1951-1955 Conservative Government and the racialization of Black Immigration'. Kwesi Owusu (ed.) Black British Culture and Society: A Text Reader (London: Routledge, 2000), pp.21-36. See also Anthony Reddie, with Wale Hudson-Roberts and Gale Richards (eds.) Journeying to Justice: Contributions to the Baptist Tradition Across the Black Atlantic (Milton Keynes: Paternoster Press, 2017).

${ }^{32}$ Anthony B. Pinn Terror and Triumph: The Nature of Black Religion (Minneapolis: Fortress press, 2002), pp.12-77
} 
was a Black teenager of blameless character who was brutally murdered on the April $18^{\text {th }}$ 1993, in the South-East London borough of Eltham.

In this notorious case, one witnesses the existence of what I have termed 'contractual compassion' within the body politic of the nation. In using his phrase, I am arguing that the strictures of a repressed and dichotomous form of dualism ${ }^{33}$ (one that divides the world and people into those who are righteous and 'of God' and those who are of 'the World' and are not) is one that makes crucial determinations between those who are deserving, and those who are not. We see this form of contractual dualism in how we assess issues of social class and economics. We have the language of the 'deserving and undeserving poor', some poor people deserve support and encouragement whilst other people deserve to be punished for their lazy and feckless behaviour. Curiously and perhaps, unsurprisingly, we have no equivalent language for the undeserving rich!

In the case of Black bodies, because we are seen as the 'other' and are inherently transgressive and accompanied with a problematic ontology, sympathy, and therefore justice, as a response to racialised violence can only become operative when the recipient of such violence is seen to be blameless. That is to say, a form of respectability politics are at play in terms of how Black lives are assessed for their worth and value. It is no coincidence that in the case of Stephen Lawrence, when the police first arrived on the scene of his murder, their first instinct was to assume that he was guilty of something, even though he lay on the ground fatally injured. ${ }^{34}$

\footnotetext{
${ }^{33}$ Kelly Brown Douglas explores the theological dualism within platonized Christianity in her book What's Faith Got to Do With it?, pp.109-149

${ }^{34}$ Ligali, The African campaigning group based in the UK are claiming that racial violence directed at people of African descent is on the increase. In a report from the $12^{\text {th }}$ September, 2007, they claim that "A mob of violent racists who have been responsible for a number of attacks on African people are being sought by police in Tilbury, Essex. Essex Police have increased their presence in the Tilbury area, particularly around the railway station and business areas, following a number of verbal and physical assaults targeted at the local African community. Three attacks have been reported this month alone although the spate of attacks has been occurring at a rate of one every week since July 2007." Taken from 'Crime and Justice News', - from http://www.ligali.org/index.php - Accessed 27th July 2018
} 
The next line of inquiry was predicated on the notion that he was a member of a gang and that this incident, which subsequently led to his death, was a product of gang-related violence. It was only when all the traditionally racialised lines of inquiry had been exhausted and no apportion of blame could be levelled at this Black youth of 'dubious character and virtue' that the British press then threw their weight and influence behind the campaign to find his killers. The support of the British press emerged once all the, hitherto, non-contested frameworks that posit the notion of Black people as the 'other' had been exhausted and not before. In terms of the controversy over the deportation of members of the Windrush Generation and their descendants, the amelioration of this state sanctioned exercise in bad faith is still predicated on the benign and passive suffering of predominantly elderly, non controversial figures. In other words, the public opprobrium at the punitive treatment of Windrush Generation was operative because these were inoffensive and largely supine, older Black people. Middle England and the machinations of the media would not have been so supportive if the people being deported were inner city Black Muslim youths of allegedly dubious character.

The toxicity of the hostile climate on immigration was such that it has helped to create a contemporary epoch in which White entitlement has reasserted itself, blaming migrants and minorities for the social ills that plague the nation. In the context of this paper on Black Lives mattering, I have noted the distinct diffidence with which the church responded to the phenomenon of Brexit, the success of which helped to fuel the state sanctioned hubris of deporting British citizens via a toxic environment for which many White people voted. I have yet to find any church leader who has identified, unambiguously, with the cause of marginalised Black and minority ethnic people who have been othered in the Brexit phenomenon, which gave rise to the policies of the former Home Secretary, Amber Rudd. I have personally sat in meetings and watched and listened to predominantly White leaders 
pander to the toxic rhetoric that others? Black bodies and minority ethnic migrants in order to placate the wounded psyche of White privilege and entitlement. Ironically, many show more care for dissatisfied and disillusioned White people who largely do not attend their churches than to Black migrants who do so, in disproportionately large numbers - often maintaining inner cities after they had been vacated by 'White flight' in the 1980s and early 90s. In making this comment, I am not suggesting that White majority do not have Black leadership within their churches or that Black people are not evidence in leadership positions. My critique of the apparent silence of White leaders refers to the lack of any substantive challenge to the rampant xenophobia and racism of the Leave Campaign and its vilification and othering of visible migrants and the anti-immigration discourse that underpinned Brexit. It can be argued that alongside the National Health Service, London Transport and British Christianity, especially White majority churches have been the greatest beneficiaries of immigration from the countries of the former British empire. ${ }^{35}$ The failure of White leaders to challenge the tone and even the legitimacy of the anti-immigration rhetoric of the Leave Campaign was a failure to appreciate the significance of the Black contribution to churches in the inner city conurbations, often existing as Black enclaves long after White middle class people had left and without any significant presence of White working class people many whom voted in significant numbers for Brexit.

\footnotetext{
${ }^{35}$ The importance of Black Christianity to the multicultural nature and expression of the faith in historic churches has been expressed in a number of reports and publications. See Faithful Cities-A Call For Celebration, Vision and Justice (Peterborough and London: The Methodist Publishing House and Church House Publishing, 2006), Anthony G. Reddie, with Hudson Roberts and Gale Richards (eds.) Journeying to Justice: Black Contributions to the Baptist Tradition Across the Black Atlantic (Milton Keyes: Paternoster press, 2017), https://www.urc.org.uk/about-us/global-and-intercultural/197-global-and-intercultural-ministries.html Accessed 4th July 2018, Tessa D. Henry-Robinson 'Qualitative Account of a Relationship Story Between the URC and BME Women'. Black Theology: An International Journal, Vol.12, No.1, 2014, pp.58-79. See also David Isiorho 'A Tale of Two Cities: Implicit Assumptions and Mission Strategies in Black and White Majority Churches'. Black Theology: An International Journal, Vol.10, No.2, 2012, pp.195-211

For helpful texts outlining the growth in Black Pentecostalism in the UK see Israel Olofinjana, Joel Edwards and Ram Gidoomal Turning the Tables on Mission: Stories of Christians from the Global South in the UK (London: Instant Apostle, 2013), Israel Olofinjana African Voices: Towards African British Theologies (Carlisle: Global Christian Publications, 2017). See also Joe Aldred and Keno Ogbo (eds.) The Black Church in the $21^{\text {st }}$ Century (London: DLT, 2010). See also David Isiorho 'A Tale of Two Cities: Implicit Assumptions and Mission Strategies in Black and White Majority Churches'. Black Theology: An International Journal, Vol.10, No.2, 2012, pp.195-211.-
} 
It is interesting to note the ways in which church leaders in Britain whilst challenging the more jingoistic elements of the Leave Campaign, nevertheless, refused to critique the concerns over immigration as being part of an orchestrated attempt at obfuscation. So, blame can heaped upon migrants for the strain on resources that are disadvantaging the entitlement of poor White people whilst ignoring the neo-liberal social and economic policies that have marginalised these communities for the past two hundred years. The latter occurred whilst British imperialism was being orchestrated across the world, when migrants were not much evidence in the country. ${ }^{36}$ As I reiterate, Black lives do not matter in the body politic of Great Britain!

\section{The Challenge to White Christianity in Britain - For Black Lives to Matter}

Black Christianity in Britain has challenged the scourge of racism as it has sought to effect unity within the Body of Christ in terms of the catholicity of the Christian faith. Black Christianity has sought to challenge White Christianity in Britain. Black Christianity has challenged White Christianity to live out the gospel imperative to love one another as Christ has loved all humanity. The challenges of John 12:34-35 and loving one another irrespective of difference are real and have offered a critical dialectic for White Christianity in Britain for centuries. This new commandment from Jesus sits at the heart of the Christian message and has implications for those inside and outside the community of faith. Inside the faith, the followers of Christ are asked to love another for 'by this, everyone will know that you are my disciples' (v.35). The way in which the followers love one another will be a sign of their commitment to and belonging within the common life of faith in Christ Jesus.

\footnotetext{
${ }^{36}$ See the following link for a news story in which the Archbishop of Canterbury is seen to buy into the toxic narrative of immigration concern in the UK prior to the Brexit vote. https://uk.reuters.com/article/uk-britain-euchurch/british-fears-over-immigration-should-be-addressed-archbishop-of-canterbury-idUKKCNOWDOSC Accessed 4th July 2018
} 
The fundamental problem with Christianity in Britain is that its ethical basis has been undermined by a deep seated sense of White exceptionalism that has its roots in British history as we have seen. The subterranean notions of White normality, with its concomitant characteristics of entitlement, privilege and superiority is so deep seated that it permeates all manner of discourse around Christianity and its associated ethics within the British context.

We can see the aforementioned in the rise of populist nationalism in the UK, which formed the substratum of the Brexit phenomenon. The aggressive polemics of the Leave campaign and the visceral anti-immigration discourse that underpinned Brexit has been explored more recently by a number of predominantly White British theologians. ${ }^{37}$ Whatever one thinks of the merits or otherwise of the Brexit campaign, one cannot doubt the significance of how the Leave Campaign was able to tap into a subterranean ferment of discontent amongst White British people, particularly amongst disenfranchised poor White people. The toxicity of the Leave Campaign focussed a great deal of its invective on the issue of immigration. Ben Ryan, writing the introduction to his edited text Fortress Britain, ${ }^{38}$ argues for the legitimacy of interpreting the Brexit phenomenon through the refracting lens of Christian ethics because

There are good reasons for taking a particularly Christian approach seriously on these issues. For one thing, Christianity provides a language in which the British and the migrant communities can converse. For the former, although fewer than ever before now self-identify as Christian (the most recent British Social Attitudes survey found that 53 percent of British adults now have no religion and only 41 percent are Christian), the UK remains a place shaped by its Christian history and values. ${ }^{39}$

Ryan and the various contributors to this important text provide incisive and cogent arguments for exploring the ethical concerns surrounding immigration policy and the impact of migration on the body politic of Britain. Of particular import in the context of this paper is

\footnotetext{
${ }^{37}$ See Ben Ryan (ed.) Fortress Britain?: Ethical Approaches to Immigration Policy for a Post-Brexit Britain (London and Philadelphia: Jessica Kingsley, 2018) and Crucible: The Journal of Christian Social Ethics Populism [April Issue] (London: Hymns, Ancient and Modern, 2018)

${ }^{38}$ Ben Ryan (ed.) Fortress Britain?, 2018

${ }^{39}$ Ben Ryan (ed.) Fortress Britain?, p.9
} 
the essay by Susanna Snyder. ${ }^{40}$ Snyder's excellent essay outlines biblical and theological perspectives on migration, reminding us that

The starting point in any discussion of migration in the Bible has to be that the people of God are migrants themselves. Being on the move is part of our identity as human beings, and the themes of strangeness, travel, journeying and uprooting weave their way through the Bible as a recurring thread. ${ }^{41}$

Throughout her essay Snyder outlines the critical challenges presented by the transnational identity of Christianity, in which the 'people of God' is not restricted to any particular land mass and in which notions of solidarity are not limited to one's immediate ethnic or cultural group. In a telling concluding comment, Synder states

Finally, the visio dei - or vision of God - reminds us to raise our eyes to see over the boundary walls and barbed wire fences we have constructed around nation states, and to revitalise our sense of connection with all people rather than just those within our particular nation. ${ }^{42}$

Although Snyder does not explicitly name 'Whiteness' as a concern, she nevertheless, calls into question the inherent theology of election that permeates British, particularly English, identity in terms of its axiomatic sense of entitlement and specialness as a people. Snyder interprets the notion of 'God's people' in its correct, transnational identity, countering the more myopic and bounded sense in which it is used as a bulwark for White British nationalism.

Whilst Christianity has rightly sought to preserve the ideal of universality and unity, the growth of the Christian church worldwide has also been predicated on the realisation that every branch of its worldwide body is some particular expression of the faith. Every particular manifestation of church is one that is attendant with specific social and cultural markers that identify it as something distinct within the overall macro phenomenon of the faith. Nigel Rooms' book The Faith of the English attempts to contextualise the Christian

\footnotetext{
${ }^{40}$ Susanna Snyder 'Biblical and Theological Responses on Migration', pp.94-113

${ }^{41}$ Susanna Snyder 'Biblical and Theological Responses on Migration', p.96

${ }^{42}$ Susanna Snyder 'Biblical and Theological Responses on Migration', p.110
} 
faith in England in order that there is a dynamic synergy between cultural expression and identity and any concomitant faith in Jesus Christ. ${ }^{43}$

The problem with the contextualisation of British and more specifically English Christianity, is that it is rarely, if ever, undertaken in a way in which the sub-textual nature of Whiteness and notions of 'manifest destiny' of empire and colonialism are taken into account. ${ }^{44}$ The issue at stake is not whether Christianity in Britain can and should be contextualised, for, clearly, every manifestation of the Christian faith in any context represents some element in the localized, adaptation of belief and practice, as one would expect in terms of all cultural expression and its relationship to faith expression. ${ }^{45}$ Rather, the salient issue for me, in terms of my theologizing around Black bodies and our resultant lives, is the exceptionalism of British, specifically English, identity, which makes the process of contextualisation a potentially toxic undertaking for those people who are Black and perceived as the other within the body politic of the nation. How does one assert the ethical nature of the church when the body of Christ is rife with racism?

White English Christianity must be committed to a ruthless and fiercely argued critique of its Whiteness, in a manner that accords with the existential dialectic that Black people have been obliged and sometimes forced to undertake since the creation of modernity. ${ }^{46}$ In critiquing Whiteness, I am talking about a thorough deconstruction of the toxic relationship between Christianity, Empire and notions of White-British superiority. ${ }^{47}$

\footnotetext{
${ }^{43}$ Nigel Rooms, The Faith of the English (London: SPCK, 2011)

${ }^{44}$ For an excellent distillation of this sense of 'manifest destiny' that underpins Anglo Saxon inspired notions of Whiteness that reflects both British and Americans notions of selfhood, see Kelly Brown Douglas Stand Your Ground: Black Bodies and the Justice of God (Maryknoll, New York: Orbis, 2015), pp.4-23

${ }^{45}$ For excellent work in respect of how Christianity is contextualised in relationship to cultures and practices in specific mileus, See H. Richard Niebuhr Christ and Culture - $50^{\text {th }}$ anniversary edition. (San Francisco: Harper Collins, 2002), Stephen B. Bevans Models of Contextual Theology (Maryknoll: Orbis, 2002), Robert Schreiter Constructing Local Theologies (Maryknoll: Orbis, 1985), and Gerald A. Arbuckle Earthing The Gospel: An Inculturation Handbook for Pastoral Workers (Eugene, Or: Wipf and Stock, 2002).

${ }^{46}$ Perhaps the best work that addresses issues of Whiteness and privilege in Christian theological terms is Alison Webster You Are Mine: Reflections on Who We Are (London: SPCK, 2009).

${ }^{47}$ Anthony G. Reddie Is God Colour Blind?: Insights from Black Theology for Christian Ministry (London: SPCK, 2009), pp.37-52
} 
My work in the UK as a Black British liberation theologian has been informed by the continued toxicity of racism and White privilege and entitlement. My scholarship emerges from my own existential challenges of being a Black British born male theologian existing in an academic and ecclesial context in which I am often one of only a few non-White people present, where, for the most part, White people often fail to notice that people who do not look like them are invariably not present. I have lost count of the number of times I have been the only Black person in a room at either academic or church related events and no one has commented unless I chose to do so. White normativity continues to create a template in which Whiteness and their concomitant experiences matter a great deal more than the claims and needs of Black people. In effect, Black lives do not matter unless they are constrained within respectability politics in which Black bodies are expected to conform to Eurocentric norms. $^{48}$

The quest for equity, liberation and justice is one that requires the committed determined action of all peoples. It also requires truth telling and a retreat from all forms of obfuscation that blind us to the structural and systematic forms of racism that continue to oppress Black people and other minority ethnic people in Britain. Whether we wish to acknowledge it or not, privilege, and notions of who is important, has a colour. Similarly, systemic power and notions of belonging and what is deemed acceptable also has a colour. The failure to name and unmask these forms of unearned privilege has been, for me, the most telling indictment of White Christianity in Britain, which in turn, has besmirched the very concept of catholicity in the Christian faith. Anti racism is essential if Christianity is to preserve its cherished belief as being one, holy, catholic and apostolic body. In an age of Brexit and the growing instances of White, nationalistic populism emerging across 'Christian Europe,' White Christianity must remain committed to the liberative qualities of Christ as its true Lord and Saviour and reject the heresy of White superiority. The days of Black people having to struggle with the

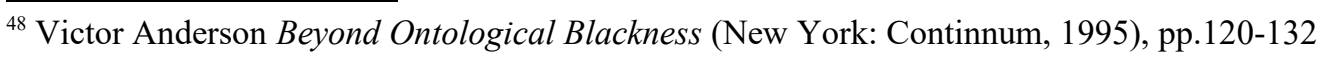


pernicious patterns of socio-cultural and religious "double jeopardy" (we have to solve our own problems and those of White people also, who for the most part, have to failed to address their own Whiteness) should be at an end.

The task of unmasking the privileged construct of Whiteness is not a task for Black Christians alone, especially their relatively few Black liberation theologians. Conversely, the task of effecting the systemic and structural changes that better reflect the Kingdom of God within the body politic of the UK is a task for us. The catholicity of the church is imperilled in the age of Brexit, when nationalism and xenophobia trump (pun intended) faith adherence and solidarity with all peoples, across boundaries and walls. The challenge to Christian ethics in the age Brexit arises from the reality that the vote leave campaign was predicated on a rampant xenophobia and racism aimed at non-White people, with which many Christians agreed and for which many voted - as did quite a few Black people as well, it has to be said. The task of challenging the toxicity of White privilege is necessary if the universality and inclusivity of the church is to be continually realised. When British Christianity utterly deconstructs it collusion with imperialism and White privilege, seeking to embrace a more expansive identity that rejects nationalism and the little Englander mentality, then and only then, will Black Lives truly matter in Britain. I long for that day to come!

Professor Anthony Reddie

Extraordinary Professor, Theological Ethics

University of South Africa

NRF 'A Rated' - Leading International Researcher

http://www.anthonyreddie.com/

Editor:

Black Theology

An International Journal

www.tandfonline.com/yblt 
